\title{
Political Reposition of Authority in South Nias DPRD Members in 2014 Election (A Study on Social Construction of Peter L. Berger)
}

\author{
Hadirat Manao \\ Postgraduate Students of Social Science in Universitas Airlangga, Surabaya, Indonesia \\ b4khrul.4m4l@gmail.com
}

\section{Abstract:}

The establishment of South Nias Regency is of course accompanied by the formation of new legislative and executive institutions to run the government. The formation of these institutions provided an opportunity for the emergence of local Nias Selatan Elits to take up positions as legislators and regional heads. Reflecting from the above view, this research is a case study that focuses on developing in-depth descriptions and explanations of the meaning of the position of legislative members in South Nias in 2014. specifically the perspective of Peter L Berger's social construction. reality of the meaning of office is in the view of members of the South Nias DPRD, namely as a mandate, arena of contestation, and aspects of interests. The factors underlying the interest of South Nias DPRD members towards positions were formed in two spheres, namely the individual domain and the community domain. In the individual domain, their interest in the position is motivated by four factors, namely internal motivation, external motivation, skills, and goals. While in the community domain there are three factors, namely the previous orientation, current orientation, and future orientation.
Keywords

Politic reposition;

South Nias DPRD

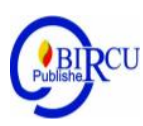

\section{Introduction}

In Indonesia, the political elite is trying to build the image to gain sympathy from the community, so that the intensity of competition in the public space, including in the media looks very clear. According to Nyarwi Ahmad, there are three things behind the increasing intensity of imaging political battle, namely the tight competition between contestants, the high demand of society and cultural factors. First, the tight political competition between parties or between candidates fought in political contestation. This example can be considered how the political competition ahead of the arena of Legislative Election, Election of DPD, Presidential Election and Election of Regional Head. The political struggle is not only related to the actual condition of each political party, but also related to the candidates. (Azhar, 2018)

Political repositioning shows that opportunistic structures of power, capital or economy, culture and kinship or dynasty were used by the Elites to strengthen their political base in the face of the 2014 legislative elections. The combination of elite position and repositioning patterns in South Nias has implications for the way in political recruitment for nominating members legislative. This means that the sources of party political recruitment for legislative candidates are increasingly diverse by utilizing the socio-cultural network of legislative candidates. From the party point of view, the source of recruitment of candidates 
has increasingly expanded by utilizing not only the party's formal structural path, but the party is more creative in recruiting economic, socio-cultural elite figures in preparation for the nomination of the 2014 legislative elections. While in terms of the Elite, there is a strengthening and expansion of the use of just an economic basis to cultural networks and / or kinship for political strengthening in facing the 2009 and 2014 legislative elections. This phenomenon then underlies the dynastic political practices in South Nias.

The researcher feels interested to look deeper into the political repositioning of the power of South Nias DPRD members. This refers to the consolidation that took place to perpetuate power in South Nias. The frame of the discussion will be interesting if it is discussed using the construction of Berger's thinking in seeing reality, where humans are able to manifest themselves in the products of human activity available, both for their producers and for others as elements of shared life. In other words, Berger's understanding of the reality helps researchers to see the political repositioning of the power of DPRD members in South Nias in the 2014-2019 period. Where every member of the DPRD is able to manifest itself in the institution. The manifestation process is interesting if seen in what Berger calls social construction where to see a social building of a person can be seen in three stages, namely objectification, internalization and externalization. This is what makes this research interesting to discuss more deeply.

\subsection{Dialectical Berger's Social Construction Sees Power of the DPRD}

Dialectic social construction on the power of DPRD members based on Peter L. Berger influenced by the socio-cultural world. Occur in three simultaneous externalization, objectification and internalization as discussed earlier. Below these three processes will be explained (Berger, 1991).

According to Berger the externalization process is the process of adjusting itself to the socio-cultural world as a human product. This is a continuous outpouring of human beings into the world, both in their physical and mental activities. It must be acknowledged that the existence of objective social reality is found in the relationship of individuals with social institutions.

Objectivities is the bearing of the products of that activity in social interaction with institutionalized intersubjectives or undergoing an institutional process. (Berger, 1991) At the moment of objectivities there is a process of differentiation between two social realities, namely the reality of the individual self and other social realities that are outside it, so that reality becomes something objective.

Internalization is the re-absorption of realities that exist outside the individual and transforming them from the objective world structure into the subjective world consciousness structure. Through internalization, humans are the product of society. At the moment of internalization, the objective world of social relations is reinserted into the individual, so that it seems to be within the individual. The withdrawal process involved institutions in the community (Berger, 1991).

\subsection{The Concept of Political Repositioning of DPRD Members' Power}

The concept of repositioning itself has not been put forward by many experts in the field of government, but lately often with the rise of issues regarding bureaucratic reform, the view of repositioning has begun to be widely discussed as one part of institutional changes in government. Repositioning is generally known as changing from an old position to a new 
position. While in relation to governance, the context of bureaucratic repositioning has actually been put forward by Osborne and Plastri (Osborne, 2000).

The fundamental transformation of public system and organization to create dramatise increases in the effectiveness, efficiency, adaptability, and capacity to innovate. This transformation is accomplished by changing their purpose, incentive, accountability, power structure and culture.

In other words, the repositioning of power politics is the change of one's position or position or title from the old to the new position. Or in the context of this research is a change in the position of a figure that previously held a position and is now a part of the dynamics of local politics. This description of local political reposition is like a figure who was previously active in the world of education, building schools, educating the life of the nation then seeing other opportunities in the political world and participating in the constellation of DPRD elections with various motives.

The motive referred to in this case is back to the goal of a figure to move forward in the election. Such as education figures, who have the goal to participate in political constellation to be actively involved with budgeting and strategic rules related to education. Being a member of the DPRD will give authority to oversee education policies and budgeting in the regions.

\section{Research Methods}

This research method is a qualitative method with a social construction approach. This approach defines human existence as something that must be interpreted. This study seeks to understand the political repositioning of DPRD members for the competing local elite of South Nias.

\section{Discussion}

\subsection{Social Processes Externalizing Moments.}

In the context of power as a member of the South Nias DPRD, externalization occurs when the political elite gives a discourse about power. Individuals are socialized by people around him that work as an official is good and noble. In an individual family and community environment the informant named Agustana Nduru said that the work as an official of the people must be achieved in order to advance South Nias.

This externalization begins when the individual captures the views of the public about the power of the political elite. The community said that officials were good jobs, representing the people and making progress in their regions. Good things that should be done by someone in his life, in this case related to the community environment (Berger, 1991).

Informants develop in the different social backgrounds of life. However, all informants received the same discourse regarding their work as officials or people's representatives. Work as an official is good for students. Although not directly taught by parents or family. All have the principle that work as an official is a good thing to do as well as being a priest or pastor who serves the community wholeheartedly for a prosperous life. 
Everyday life provides something objectively. Every individual is born and developed in a society that has a strong influence on the individual. As stated above, the influence arises from the family and community. So from there the child is born of an ideological similarity and the child is taught with certain teaching patterns and actions so that the child can accept it as reality.

Parents as educators at home also have the desire to teach good things to their children. Parents want a good child, working as an official will raise the good name of the family because it is clear that it will raise the status of parents. Broadly speaking, parents know about the activities of their children who always want their children to get along in a good environment. Therefore understanding of work as an official is good and noble work taught to children.

\subsection{Objective Moment Social Process}

In the context of power as a member of the South Nias DPRD, objectivity momentum occurs when someone begins to fuse with many individuals and interact. On this momentum one carries objective thoughts from the results of his externalization activities. Thus objectivities designs a process whereby the social world becomes a reality that is able to hinder or also shape its participation.

The ten informants claimed to enter politics and serve as political elites influenced by their friends. The act of working as a political official by the ten respondents has a different reason. They proudly hold official status because they consider the act of working as an official as trustworthy and trusted by the community. Responsibilities that must be shouldered when they are of public concern. They must work hard to voice people's rights and develop the region. When they succeed, the people will fall in love and continue to elect them to serve as regional leaders.

The ten informants who are members of the South Nias DPRD claimed to work as officials oriented to one goal, namely power. They believe that relations will draw closer and this is good for their interests, so they enthusiastically pursue that power. Working as an official carried out by them is considered a golden road to meet their needs. Armed with the reasons of the interests of the people they do so even though many people are their rivals.

The foregoing was explained by Berger and Luckman who said community institutions were created and maintained or changed through human actions and interactions. So even though society and social institutions look objectively real, in reality everything is built in a subjective definition through a process of interaction.

\subsection{Social Process Moment Internalization}

After going through the first two stages of momentum, enter the final stage of the process of internalization. In this internalization process, individuals re-infiltrate reality formed in society as an objective structure and apply it within themselves as subjective reality.

There are two important stages before referring to the process of how South Nias DPRD members construct their work. That stage is at the stage of introduction or initial meaning (externalization) to see their understanding of the work of officials. Then the second is the implementation phase, which is an attitude when in the community. 
Each informant has a different meaning about work as an official. This meaning is obtained from several stages which then lead them to a belief in thought (subjective) to act on the discourse (objectivity) that they have been receiving.

The meaning of power when a member of the South Nias DPRD before becoming an official and after entering politics as an official experiences several changes. This change that emerged as a subjective criticism later made members of the South Nias DPRD construct what it meant to be an official's job. Apparently found two views about the meaning of work as an official. Namely the job as an official as a mandate. While some informants interpret the job as an official it is a result of a need.

\subsection{Political Reposition of South Nias DPRD Members}

South Nias DPRD members are political elite officials in South Nias. They have their own meaning related to the actualization of themselves as officials. Their experience, their awareness of everything related to power, and the social actions that occur between them and their environment, have a role in the construction of the reality of the political repositioning of power socially in their own views.

Their status as holders of power and power, the majority of whom are important people in South Nias, is a deliberate act of awareness of the values of power for them. The values of power referred to here are interests in the form of feeling happy, proud, and powerful when in office. The political reposition of power in South Nias DPRD members is interpreted from three aspects, namely from the mandate, the arena of contestation, and the aspects of importance.

Referring to the Berger social construction that focuses on awareness, deliberation, to individual knowledge of the object, the writer gets an overview of the process. The awareness of legislators from South Nias DPRD towards power is seen in how they view and value power. Their intention to enter politics and become officials is a form of their decision based on their evaluation of power itself.

\section{a. Power as a mandate}

Power, for believers or religions, especially those related to the interests of many people, if understood and lived the spiritual meaning behind it, will be placed as a mandate that must be fulfilled by the bearer. Not as social prestige. The more so if the mandate of the power carried is accepted with an oath of power. The moral responsibility is much higher, so the higher the level of worldly temptation, not only comes from within the person holding the mandate of power, also from his immediate family. This is in line with what was revealed by Marthalena Duha.

""Position is a deposit, on the basis of that he will fight if

he is trusted. For that reason, I try to say how the people who voted for me continue to trust me ". ${ }^{1}$

If one day obtains the throne, no joy, especially excessive. The more so if the power is directly related to the interests of the people or the people. Such power, for that who realize

\footnotetext{
${ }^{1}$ Results of an interview with Martalena Duha on December 10, 2017 at the South Nias DPRD Office
} 
the meaning behind it, is received with great caution, whether he is able to carry it and fulfill it, without running away from the responsibilities given to him. Thus Sapotianus Manao's informant realizes that having power as a member of the DPRD is not just a job status. But how he can utilize all of himself and his thoughts to be able to serve South Nias.

There may be a glimmer of joy or happiness that arises when the power is given to him, but he is nothing more than an expression that he has been trusted by many people to assume that power. We can see Adil Harita's opinion. He worked as a member of the DPRD, not a peak. For him to be a member of the legislature means the calling of the soul, how someone is able to provide the best thing for his area.

"I was chosen by the people of South Nias, and will advance again for the people of South Nias. I am sure there are still those who support me later, but I realize this is not easy especially as more and more parties may intend to overthrow me. "2

In general, DPRD members can be said to have a spiritual understanding of the power they entail. They are aware of the mandate that they must carry to carry out. Therefore they always try to give the best to the people who have trusted them.

\section{b. Power as an arena for contestation}

When you become a ruler, whatever your desires will come true while the salary is never reduced at all. The necessities of life for a ruler are borne entirely by the state. Not to mention the official travel facilities here and there that is allowed to bring family groups with him. There is no one who is paid, served and prospered like that so the others are fighting over to achieve the same thing.

The way the state exalts a ruler is clearly quite excessive. All people, from all directions and from all directions are able to witness the luxury and splendor. The human being is filled with jealousy so automatically when there is someone who is treated too special there must be someone who is jealous. Jealousy is what often makes some people fight over it for personal gain.

A ruler has the authority to determine this and determine it. While many people who want him to stay there or settle there. Therefore, a lot of respect, praise, popularity and money are directed at him so that everything is smooth, everything is smooth; those who want to be officials are given facilities. This is one of the tempting attractions to fight for a position as ruler of the country. Others will flock to sacrifice billions of rupiah in wealth as a ticket to become a ruler because he knows that when he sits on top he will receive more wages.

\section{c. Power as the realm of interests}

South Nias DPRD members construct their own political power repositioning based on the experiences they have experienced as power holders and as members of political parties. The author gets the picture that their awareness in the form of an interest in power is motivated by several factors.

\footnotetext{
${ }^{2}$ Results of an Interview with Adil Harita on December 10, 2017 at the South Nias DPRD Office
} 
Based on interviews conducted, the author gets a picture of the factors that affect the interests of members of the South Nias DPRD towards power, including: internal motivation, external motivation, skills, and goals.

The internal motivation referred to here is the arising of likes, pleasures, hobbies, and an individual's interest in the power itself. Whereas the external motivation that constructs the political repositioning of power for them is the environment, namely the environment of family, friends, and exposure to information from the mass media. The goal, which is to eliminate the stigma of political officials inherent in society.

In other words, they want to serve the community wholeheartedly and prove that the stigma attached to officials in the community depends on certain contexts and points of view. The skills possessed by the informants contribute to the interpretation of power. One of the informants interviewed by the writer, Faduhusa Laia, said that his involvement in politics and becoming an official was an effort to channel his talents in education, namely political education. Whereas other informants said that their skills in becoming leaders and in positions were obtained by self-taught by learning from their political party friends.

Berger and Luckmann explain that the formation of the world and social reality through simultaneous stages, namely externalization, objectivities, and internalization. In this stage, there are realities that are seen as subjective, objective, and symbolic. Society according to Berger and Luckmann can be seen as subjective reality and objective reality.

Members of the South Nias DPRD carry out internal communication activities in the form of exchanging information on matters relating to the development of politics and power. Among these, members used to gather to exchange information related to prospective leaders or candidates who would advance to the arena of the elections. In addition to discussing matters relating to the Indonesian political world, ordinary members gather to discuss what activities will be carried out for the advancement of South Nias.

\section{Conclusions}

Berger's hypothesis about social construction is seen in this study in the efforts of Members of the South Nias Legislative Council in the 2014-2019 period to achieve this position in a variety of ways they have and understand. Then their efforts in maintaining their position or influence in the community or constituents who choose to continue to establish good communication with various programs or efforts to answer the aspirations of the people.

The motives of South Nias DPRD members in choosing to become officials in the ranks of the government bureaucracy are to become direct actors in the development of the South Nias region. Being an official for South Nias DPRD members is important than the power held by people who do not care about the development of South Nias. If power is held by people who do not understand the history, culture and customs of South Nias, it will be fatal.

In general, this paper looks at how the political repositioning of the power of South Nias DPRD members in the 2014 elections perpetuated the politics of clans or power based on primordialismorde space. From the composition of elected DPRD members, it has been shown that the number of elected members has a close relationship with the regent. This condition reinforces that clan politics cannot be separated in the dynamics of local politics. 
Where each region has its own form in running the politics of this clan. South Nias shows this by the presence of legislative members who have kin relations and are connected to each other in supporting strategic policies in South Nias. The clan politics that occurred in South Nias gave the researcher a view that the political repositioning of the power of South Nias DPRD members in the 2014 elections could not be separated in the political motives of the clan.

\section{References}

Azhar, A. (2018). Marketing of Political Communication Created by National Mandate Party (PAN) in General Election 2005-2015, North Sumatra, Indonesia. Budapest International Research and Critics Institute (BIRCI-Journal). 93-106.

Berger, Peter L. and Thomas Luckmann,. (1991). Tafsir Sosial Atas Kenyataan.Jakarta: LPES.

Berger, Peter L. (1991) Langit Suci, Agama Sebagai Realitas Sosial. Jakarta: LP3ES.

Osborne, David. and Plastrik, Peter. (2000) Memangkas Birokrasi: Lima Strategi Menuju Pemerintahan Wirausaha, terjemahan. Abdul Rasyid dan Ramelan, Jakarta: PPM.

Hasil wawancara dengan Marthalena Duha tanggal 10 Desember 2017 di Kantor DPRD Nias Selatan

Hasil Wawancara dengan Adil Harita tanggal 10 Desember 2017 di Kantor DPRD Nias Selatan

Rauf,Maswardi dan Mappa Nasrun, (1993).Indonesia dan Komunikasi Politik. Jakarta: PT Gramedia Utama.

Rogers, Everett M dan F. Floyid Shoemaker. (1981). Communication of Innovations, terj. Abdillah Hanafi. Surabaya: Usaha Nasional.

Rush, Michael dan Philip Althoff. (2004) Pengantar Sosiologi Politik. Jakarta: PT. RajaGrafindo Persada.

Ruslan, Rosady. (2007). Kampanye Public Relation. Jakarta: PT RajaGrafindo.

Ruslan. (1997). Strategi Public Relations, Bauran Public Relations. Yogyakarta: Pustaka Pelajar,

Sahid, Komarudin. (2015). Memahami Sosiologi Politik. Bogor: Ghalia Indonesia. 